\title{
IMPLEMENTASI PERAN WALI KELAS DALAM PELAKSANAAN BIMBINGAN DAN KONSELING DI SMK NEGERI 1 BENAKAT
}

\author{
Surya Dharma Atmaja ${ }^{1}$, Edi Harapan ${ }^{2}$ Nurlela $^{3}$ \\ Universitas PGRI Palembang ${ }^{1}$ \\ Email: suryadharmaa05@gmail.com \\ Universitas PGRI Palembang ${ }^{2}$ \\ Email: ehara205@gmail.com \\ Universitas PGRI Palembang ${ }^{3}$ \\ Email: nurlelampd9@gmail.com
}

\begin{abstract}
ABSTRAK
Masalah penelitian ini adalah bagaimana implementasi peran wali kelas dalam pelaksanaan bimbingan dan konseling di SMK Negeri 1 Benaka. Tujuan penelitian ini untuk mengatahui implementasi peran wali kelas dalam pelaksanaan bimbingan dan konseling di SMK Negeri 1 Benakat. Subjek Penelitian yaitu peran wali kelas terhadap guru bimbingan dan konseling, sedangkan informan terdiri atas wali kelas dan guru bimbingan dan konseling. Metode penelitian menggunakan metode deskriptif kualitatif. Teknik pengumpulan data yaitu dokumentasi, wawancara dan observasi. Teknik analisis data dilaksanakan dengan reduksi data, penyajian data, dan penarikan kesimpulan dan verifikasi. Berdasarkan hasil temuan peneliti dalam penelitian dapat disimpulkan bahwa Bantuan wali kelas berjalan dengan baik hal ini dilihat dari wawancara yang telah dilakukan. Secara keseluruhan pelaksanaan layanan Bimbingan dan Konseling di SMK Negeri 1 Benakat, sudah terlaksana dengan baik. Hal ini terlihat dari kerjasama yang dilakukan oleh wali kelas, kepada guru Bimbingan dan Konseling dalam mengatasi masalah siswa yang bermasalah di sekolah.
\end{abstract}

\section{Kata kunci : Implementasi, Peran Wali Kelas, Bimbingan dan Konseling.}

\section{ABSTRACT}

The formulation of the research problem is how the implementation of the role of the homeroom teacher in the implementation of guidance and counseling at SMK Negeri 1 Benakat? The purpose of this study was to determine the implementation of the role of the homeroom teacher in the implementation of guidance and counseling at SMK Negeri 1 Benakat. The research subject was the role of the homeroom teacher and counseling, while the informants consisted of the homeroom teacher and the guidance and counseling teacher. The research method used a qualitative descriptive method. The data techniques are documentation, interview and observation. Data analysis techniques are carried out by data reduction, data retrieval, withdrawal and leverage. Based on the findings of the researchers in the study, it can be concluded that the homeroom teacher's assistance is going well, seen from the interviews that have been conducted. In total, the implementation of Guidance and Counseling services at SMK Negeri 1 Benakat has been carried out well. This can be seen from the cooperation carried out by the homeroom teacher, with the Guidance and Counseling teacher in overcoming the problems of students who have problems at school.

Keywords: Implementation, the role of homeroom teacher, guidance and counseling. 


\section{PENDAHULUAN}

Pendidikan dewasa ini mendapat perhatian serius dari pemerintah dan masyarakat. Pendidikan menjadi tanggung jawab bersama antara pemerintah, masyarakat, dan keluarga. Hal tersebut tertuang pada Undang-Undang Sistem Pendidikan Nasional No. 20 tahun 2003 berikut ini, Pendidikan adalah usaha sadar dan terencana untuk mewujudkan suasana belajar dan proses pembelajaran agar peserta didik secara aktif mengembangkan potensi dirinya untuk memiliki kekuatan spiritual keagamaan, pengendalian diri, kepribadian, kecerdasan, akhlak mulia, serta keterampilan yang diperlukan dirinya, masyarakat, bangsa, dan negara.

Pendidikan merupakan proses untuk membantu siswa dalam mengembangkan dirinya sehingga mampu menghadapi setiap perubahan yang terjadi dalam rangka membangun manusia yang seutuhnya. Pendidikan dapat meningkatkan taraf kecerdasan peserta didik pada tahap tertentu. Dalam pendidikan, keberadaan manusia dapat dipandang sebagai makhluk yang belajar, dalam hal ini Tirtahardja (2013:131) menyatakan bahwa: proses menjadi seorang manusia atau disebut to be yang telah diprogramkan semenjak lahir, melainkan harus membut program sendiri bagi dirinya agar menjadi segala asepek yang diinginkannya untuk berkembang dan berpotensi menjadi lebih baik dan berdampak pada kehidupannya mendatang. Manusia adalah makhluk dalam dunia namun tidak terikat kepada dunia. Ia selalu berinteraksi dengan dunia sekitarnya, dan dalam interaksi tersebut ia selalu memberikan respon tertentu. Proses interaksi yang terjadi itu adalah proses belajar yang berlangsung terus-menerus, baik terhadap wali kelas, guru, staff dan wali kelas.

Bantuan wali kelas dalam pembelajaran dapat memotivasi belajar siswa sebagai usaha untuk mewujudkan pendidikan nasional khususnya untuk meningkatkan kualitas manusia Indonesia. Rasyid (2014:26) juga menambahkan bahwa Sebagian besar tanggung jawab dalam menerapkan standar penilaian terletak ditangan para guru. Maka perencanaan pembelajaran banyak tergantung kepada kemampuan guru mengembangkannya, karena tugas guru berkaitan dengan melaksanakan pembelajaran mata pelajaran yang menjadi tanggung jawabnya.

Bedasarkan hasil observasi ketika pelaksanaan Kuliah Kerja Lapangan (KKL) di SMK Negeri 1 Benakat bahwa pelaksanaan layanan bimbingan dan konseling masih 
perlu ditingkatkan dengan melibatkan seluruh komponen yang ada di sekolah, seperti wali kelas, staff, guru, dan wali kelas.

Pada umumnya siswa sekolah lanjutan adalah para remaja, dengan memperhatikan ciri-ciri perkembangan psikologis yang berbeda dalam periode transisi antara kanakkanak menuju dewasa tentulah siswa tersebut sangat membutuhkan bimbingan dan konseling. Pada situasi seperti inilah seharusnya bimbingan dan konseling di sekolah dibebankan kepada orang ahli dibidangnya. Akan tetapi proses Bimbingan dan Konseling di SMK Negeri 1 Benakat berjalan apabila ada siswa yang bermasalah, maka guru Bimbingan dan Konseling akan memanggil siswa tersebut, mencari permasalahan dan membantu menyelesaikan masalah yang dihadapi siswa tersebut dengan cara memberikan solusi yang tepat pada permasalahan yang dihadapinya, tidak semua siswa bermasalah ditangani dan dilayani oleh guru Bimbingan dan Konseling, akan tetapi semua pihak sekolah seperti guru piket, wali kelas, wali kelas diharapkan turut berperan membantu siswa mengatasi permasalahan sesuai dengan tingkat permasalahan yang ditimbulkan siswa tersebut di sekolah.

Salah satu kasus siswa yang bermasalah di SMKN 1 Benakat yakni terdapat salah satu siswa berinisial "S" sering bolos sekolah, dari absensi siswa "S" lebih banyak tidak masuk sekolah, setiap minggu siswa "S" hanya masuk dua atau tiga hari dan ketika siswa "S" masuk sekolah yang dilakukan saat jam pelajaran berlangsung siswa "S" lebih banyak tidur dikelas serta melalaikan tugas dan kewajibannya sebagai seorang pelajar. Siswa "S" adalah seorang siswa yang duduk di kelas X SMKN 1 Benakat dengan tipe orang yang acuh tetapi, ia tidak membatasi pergaulannya baik laki-laki maupun perempuan. Siswa "S" memiliki banyak teman, ia tidak membedakan siapa yang menjadi temannya baik orang yang sekolah maupun yang tidak. Siswa "S" ekonomi keluarganya tergolong ekonomi menengah keatas. "S" adalah anak pertama dari dua bersaudara "S" satu- satunya anak laki- laki dikeluarga tersebut ibu dan ayahnya selalu menuruti kemauanya nya dan tergolong anak yang manja.

Tugas guru bimbingan dan konseling dan wali kelas yaitu mengatasi siswa yang mengalami masalah di dalam kelas dan di luar kelas. Namun peran guru bimbingan dan konseling menangani siswa yang mengalami permasalahan seperti berkelahi yang hampir sering terjadi tiap minggunya, melanggar tata tertib sekolah dengan menggunakan baju yang tidak sesuai aturan dan terlambat datang ke sekolah sehingga 
harus melewati jam pertama, terlambat upacara ketika hari senin yang hampir sering terjadi tiap minggunya, sedangkan wali kelas menangani berbagai masalah siswa sepeti malas belajar, tidak mengerjakan tugas dan tidak memperhatikan pembelajaran.

Untuk menangani permasalahan tersebut, sebagai guru Bimbingan dan Konseling ada beberapa tugas yang harus dilakukan, yakni menjadikan dirinya sebagai teman dekat agar anak tersebut dapat terbuka dan menceritakan tentang masalahnya. Lalu kmemberikan nasihat pada si anak dengan tutur kata yang lembut tanpa menyinggung perasaannya. Kemudian yang terakhir, mampu membantu meluruskan masalah dengan mencarikan solusi agar si anak tidak mengulangi masalah tersebut.

Kolaborasi antara wali kelas dengan guru Bimbingan dan Konseling harus terjalin dengan baik dalam rangka mengatasi masalah yang dihadapi siswa di sekolah. Kedua komponen penting ini menjadi ujung tombak dalam mengatasi masalah siswa di SMK Negeri 1 Benakat.

Dari uraian yang telah dikemukakan di atas dan dari fenomena yang ada di SMK Negeri 1 Benakat, maka penulis tertarik untuk mengadakan penelitian dengan judul "Implementasi Peran Wali Kelas dalam Pelaksanaan Bimbingan dan Konseling di SMK Negeri 1 Benakat"

\section{LANDASAN TEORI}

Bimbingan merupakan sebuah proses yang harus dilalui oleh sejumlah individu yang memerlukan perubahan atau pengembangan diri yang lebih positif, bimbingan dilakukan oleh seseorang konselor yang profesional dibidangnya agar bimbingan tersebut dapat berjalan dengan baik dan optimal.

Menurut Lefever dalam Prayitno (2013:94), bimbingan adalah bagian dari proses pendidikan yang teratur dan sistematik guna membantu pertumbuhan anak muda atas kekuatannya dalam menentukan dan mengarahkan hidupnya sendiri, yang pada akhirnya ia dapat memperoleh pengalaman-pengalaman yang dapat memberikan sumbangan yang berarti bagi masyarakat.

Sementara Nurihsan (2014:7), mengemukakan bahwa bimbingan merupakan upaya pemmbimbing untuk membantu mengoptimalkan individu. Sedangkan menurut Sukardi, (2012:36), bimbingan adalah sebagai berikut 
Suatu proses pemberian bantuan kepada individu yang dilakukan secara berkeseinambungan supaya individu tersebut dapat memahami dirinya sendiri, sehingga dia sanggup mengarkan dirinya dan dapat bertindak secara wajar, sesuai dengan tuntutan dan keadaan lingkungan sekolah, keluarga, dan masyarakat dan kehidupuan pada umumnya.

Dengan demikian berdasarkan pendapat di atas dapat penulis simpulkan bahwa bimbingan merupakan bantuan yang diberikan kepada seseorang atau individu dalam rangka upaya menemukan pribadi, mengenal lingkungan, dan merencanakan masa depan, yang setiap keputusan akhir tetap individu itu sendiri yang memutuskannya (menentukan pilihan).dengan itu dapat di ketahui apa yang menjadi tujuan bimbingan itu sendiri.

Konseling pada dasarnya dilakukan secara individual yaitu antara klien dan konselor, yang dalam hal ini antara siswa dan guru bimbingan dan konseling yang ada di sekolah.

Tujuan bimbingan sangat perlu diketahui oleh para guru bimbingan dan konseling, mengingat hal ini akan memberikan gambaran tentang tujuan yang akan dicapai dalam mengatasi siswa yang bermasalah.

Menurut Hamrin dalam Prayitno (2013:112) tujuan bimbingan adalah "Untuk membantu individu membuat pilihan-pilihan, penyesuaian-penyesuaian, interpretasiinterpretasi dalam hubungannya dengan situasi-situasi tertentu”. Dapat di simpulkan bahwasanya tujuan dari bimbingan itu sendiri adalah untuk membantu individu dalam mengenal dirinya sendiri serta membantu setiap permasalahan yang sedang di hadapi oleh individu agar mencapai kesejahteraan hidup yang optimal.

Salah satu komponen yang ada dalam sekolah dalam mengatur proses belajar mengajar dalam kelas adalah wali kelas. Peran wali kelas tidak hanya dalam belajar tetapi dalam mengawasi perilaku dan karakteristik siswa.

Menurut Sukardi (2012:90), wali kelas adalah guru yang diberi tugas khusus di samping mengajar untuk mengelola status kelas siswa tertentu dan bertanggung jawab membantu kegiatan bimbingan dan konseling di kelasnya. Lebih lenjut menurut Seotjipto \& Kosasih (2011:102), wali kelas merupakan personel sekolah yang ditugasi untuk menangani masalah-masalah yang dialami oleh siswa yang menjadi binaanya. 
Dari penjelasan tersebut dapat disimpulkan bahwa wali kelas adalah orang membuat kelas itu secara bersama-sama berhasil menjalankan fungsi pembelajaran yang kriterianya adalah semua siswa di kelas itu dapat naik kelas dengan nilai yang baik pada akhir tahun. Wali kelas bekerjasama dengan pihak sekolah untuk merencanakan program pendampingan bagi kelas perwaliannya. Program ini harus terstruktur dalam kebijakan sekolah sehingga setiap program perwalian wali kelas memiliki visi dan misi yang sama. Wali kelas secara periodik perlu melakukan evaluasi terhadap kelasnya melalui pertemuan yang tidak formal dan lebih rileks agar komunikasi lebih bisa terbangun.

\section{HASIL PENELITIAN DAN PEMBAHASAN}

Hasil dari penelitian ini berhubungan langsung dengan variabel penelitian yaitu peranan wali kelas dalam pelaksaanan bimbingan dan konseling di SMK Negeri 1 Benakat.

Dari hasil wawancara yang dilakukan dengan dua wali kelas yakni wali kelas $\mathrm{X}$ dan kelas XI, dapat dilihat bahwa benar adanya kerjasama antara wali kelas dalam memberikan bantuan kepada siswa bermasalah berupa yang mengalami kesulitan belajar dalam mata pelajaran matematika dan fisika. Ada 3 orang yang mengalami kendala dalam mengikuti mata pelajaran matematika namun kerjasama yang dilakukan dengan wali kelas sewaktu memberikan bimbingan belajar kepada salah seorang siswa yang mengalami kesulitan dalam pelajaran matematika.

Hasil wawancara selanjutnya kepada wali kelas XI mengatakan bahwa pernah melakukan kerjasama dengan guru bimbingan dan konseling dalam memberikan bimbingan kepada dua orang siswa yang mengalami kesulitan belajar. Guru memberikan materi pelajaran yang sulit dipahami oleh siswa diajarkan kembali, sedangkan wali kelas melakukan pengontrolan terhadap perkembangan hasil bimbingan belajar yang diberikan. Kerjasama ini dilakukan sampai ada kemajuan siswa dalam memahami materi.

Lebih lanjut, wawancara juga dilakukan kepada guru Bimbingan dan Konseling diperoleh keterangan bahwa peran wali kelas dalam bimbingan dan konseling masih banyak yang belum terlaksana. Menurut pendapat guru bimbingan dan konseling yang mengasuh kelas $\mathrm{X}$ dan XI hal itu terjadi karena kurangnya pemahaman wali kelas 
dengan perannya dalam pelaksanaan bimbingan dan konseling sehingga wali kelas tidak memiliki inisiatif untuk dapat ikut serta dalam pelaksanaan bimbingan dan konseling di sekolah. Guru bimbingan dan konseling membenarkan keterangan yang disampaikan oleh ketiga wali kelas yang menjadi subjek dalam penelitian ini.

Informasi yang diperoleh dari guru bimbingan dan konseling, peran wali kelas yang terlaksana secara maksimal adalah bekerjama dengan guru Bimbingan dan Konseling, dalam pelayanan penempatan dan penyaluran siswa dalam kegiatan ekstrakurikuler yang sesuai dengan minat dan bakatnya serta dalam pengaturan tempat duduk, bekerjasama dengan guru mata pelajaran untuk memberikan bimbingan kepada siswa yang berprestasi. Memberikan informasi kepada guru mata pealajaran mengenai siswa yang membutuhkan perhatian khusus, memberikan motivasi atau dukungan terhadap siswa yang mengalami masalah belajar untuk mengikuti bimbingan belajar ataupun konseling individual bagi siswa yang mengalami masalah, menyediakan waktu untuk siswa yang teridentifikasi mengalami masalah belajar, memebrikan izin serta kemudahan bagi siswa yang ingin berkonsultasi dengan guru bimbingan dan konseling pada jam pelajarannya, melakukan penilaian pada siswa yang mendapatkan layanan bimbingan dan konseling dari guru bimbingan dan konseling.

Peran wali kelas yang terlaksana namun tidak secara maksimal adalah membantu menyelesaikan masalah-masalah sederhana di kelas yang menjadi tanggung jawabnya, membantu tugas-tugas guru bimbingan dan konseling untuk mengidentifikasi siswa yang mengalami kesulitan belajar, memberikan informasi tentang kebutuhan informasi bagi siswa kepada guru bimbingan dan konseling yang berguna sebagai masukan untuk memberikan layanan informasi dengan materi yang tepat sesuai dengan kebutuhan siswa pada setiap minggu di sekolah, bekerjasama dengan guru mata pelajaran untuk membantu siswa yang mengalami kesulitan belajar, melakukan konsultasi dengan guru bimbingan dan konseling dalam menentukan solusi dan permasalahan siswa yang melanggar tata tertib sekolah, memberikan data siswa yang mengalami masalah dan membutuhkan penanganan segera kepada guru bimbingan dan konseling, melakukan tindak lanjut terhadap informasi yang disampaikan guru mata pelajaran. Selain itu guru bimbingan dan konseling mengatakan wali kelas menjadi subjek dalam penelitian ini memahami tahap-tahap penyelesaian masalah, mulai dari dirinya yang dilanjutkan ke 
wali kelas dan selanjutnya ke waka kesiswaan kemudian ke guru bimbingan dan konseling jika tidak dapat diselesaikan diserahkan kepada wali kelas.

Bantuan wali kelas yang terlaksana seperti yang telah disampaikan, sedangkan peran-peran yang lainnya selain yang telah disampaikan belum terlaksana dengan sebagaimana mestinya. Dengan itu dapat dikatakan keterangan yang disampaikan wali kelas sesuai dengan keadaan sebenarnya.

Bantuan wali kelas terkait dengan membantu guru BK melaksanakan tugas-tugas di kelas yang menjadi tangung jawabnya. Wali kelas membantu guru BK melaksanakan tugas-tugas di kelas yang menjadi tangung jawabnya adalah yaitu dengan cara melihat absen peserta didik seperti kehadiran, sikap, masalah belajar. Adapun masalah kehadirannya seperti izin. Jika izinnya lebih dari 3 kali maka peserta didik yang bersangkutan akan dipanggil dan ditanyakan penyebab dari izin tersebut untuk mencari keterangan, sakit jika peserta didik sakit maka hal tersebut perlu meminta surat keterangan dari dokter. Alpa, jika peserta didik yang alpa sebanyak 3 kali dalam 1 bulan maka peserta didik akan dipanggil dan dikonsultasikan dan membuat surat perjanjian agar tidak mengulangi hal yang sama.

Bantuan wali kelas terkait dengan membantu guru mata pelajaran melaksanakan perannya dalam pelayanan bimbingan dan konseling, terungkap bahwa peran wali kelas dalam membantu guru mata pelajaran melaksanakan perannya dalam pelayanan bimbingan dan konseling adalah informasi yang wali kelas terima dari guru mata pelajaran tentang peserta didik yang bermasalah yaitu peserta didik itu sendiri dipanggil terlebih dahulu menanyakan penyebabnya, apakah penyebab tersebut peserta didik tidak menyenangi guru, atau mungkin bisa jadi peserta didik tidak menyukai teman sekelas.

Bantuan wali kelas terkait dengan memberikan kesempatan dan kemudahan bagi peserta didik untuk mengikuti layanan bimbingan dan konseling. Wali kelas membantu dalam memberikan kesempatan dan kemudahan bagi peserta didik untuk mengikuti layanan bimbingan dan konseling adalah memberikan izin kepada peserta didik jika dipanggil oleh guru BK kecuali sedang ujian maka peserta didik tidak dibenarkan untuk mengikuti bimbingan, jika permasalahan tersebut harus segera dientaskan pada saat itu juga maka peserta didik harus segera diselesaikan maka wali kelas juga bersedia untuk mengikuti layanan tersebut, bahkan jika saat pembelajaran berlansung maka pembelajaran mengajar ditinggalkan dan memberikan tugas untuk peserta didik di kelas. 
Guru harus memiliki pemahaman tentang anak dapat melakukan suatu pendekatan misalnya manusiawi-religius, bersahabat, ramah, jujur, memahami dan menghargai tanpa syarat dengan melakukan suatu pendekatan peserta didik tersebut dapat dibimbing dengan baik. Berdasarkan pendapat di atas maka dapat disimpulkan bahwa kesempatan dan kemudahan untuk mengikuti layanan bimbingan dan konseling yaitu disaat peserta didik dipangil, wali kelas bersedia memberikan izin untuk mengikuti layanan bimbingan dan konseling, dan guru BK juga bisa memanfaatkan waktu disaat jam istirahat, atau pulang sekolah.

Bantuan Wali Kelas Terkait dengan Berpartisipasi Aktif dalam Kegiatan Bimbingan dan Konseling. Wali kelas berpartisipasi aktif dalam kegiatan bimbingan dan konseling yaitu berdasarkan data yang diperoleh dari wali kelas dalam menyelesaikan kegiatan konferensi kasus yaitu memberikan bukti-bukti yang ada pada wali kelas dan memberikan informasi yang lebih akurat agar permasalahan tampak lebih jelas. Dalam konferensi kasus tersebut guru, wali kelas sangat terlibat untuk menyelesaikan masalah yang sedang dihadap peserta didik, adapun kerjasama wali kelas dengan guru BK yaitu dengan memberikan semangat, dorongan kepada peserta didik bahwa BK bukan tempat orang yang bermasalah saja melainkan tempat untuk menyelesaikan masalah, maka peserta didik jika mengalami masalah bisa bercerita kepada guru BK dan guru BK juga bisa membantu peserta didik untuk menangani permasalahan yang sedang dihadapi.

Menurut Burhanuddin (2009:16) konferensi kasus merupakan kegiatan pendukung atau pelengkap dalam bimbingan dan konseling untuk membahas permasalahan peserta didik dalam suatu pertemuan, yang dihadiri oleh pihak-pihak yang dapat memberikan keterangan, kemudahan dan komitmen bagi terentaskannya permasalahan peserta didik.

Berdasarkan pendapat di atas dapat disimpulkan bahwa adanya saling komunikasi antara wali kelas dan guru bidang studi dengan guru BK, beserta orang tua peserta didik untuk mengadakan pertemuan khusus atau konferensi kasus untuk menyelesaikan permasalahn peserta didik.

Berdasarkan hasil yang diperoleh berkaitan dengan kajian terdahulu yang relevan oleh Almira, (2012), yang dikutip dari skripsi Universitas PGRI Palembang "Peranan Guru Mata Pelajaran terhadap Pelaksanaan Bimbingan dan Konseling di SMA Negeri 7 Palembang". Dalam penelitiannya di dapatkan bahwa informasi yang 
diperoleh dari guru mata pelajaran sangatlah penting dalam memberikan strategi layanan bimbingan dan konseling bagi siswa. Berdasarkan kajian terdahulu yang relevan maka dalam penelitian ini penulis mempunyai kesamaan yaitu sama-sama meneliti tentang pelaksanaan bimbingan dan konseling dengan subjek yang diteliti adalah guru. Sedangkan perbedaanya adalah penelitian terdahulu mengkaji peranan yang dimiliki guru mata pelajaran dalam memberikan informasi kepada konselor, sedangkan pada penelitian ini penulis mengkaji tentang evaluasi guru bimbingan dan konseling.

\section{KESIMPULAN}

Berdasarkan penelitian yang telah dilaksanakan, maka dapat diambil kesimpulan sebagai berikut.

1) Bantuan wali kelas berjalan dengan baik hal ini dilihat dari wawancara yang telah dilakukan.

2) Secara keseluruhan pelaksanaan layanan Bimbingan dan Konseling di SMK Negeri 1 Benakat, sudah terlaksana dengan baik. Hal ini terlihat dari kerjasama yang dilakukan oleh wali kelas, kepada guru Bimbingan dan Konseling dalam mengatasi masalah siswa yang bermasalah di sekolah.

\section{DAFTAR PUSTAKA}

Adhiputra, Anak Agung Ngurah. 2013.Bimbingan dan Konseling Aplikasi di SD dan TK. Yogyakarta: Graha Ilmu.

Almira, Gina. 2012. Peranan Guru Mata Pelajaran terhadap Pelaksanaan Bimbingan dan Konseling di SMA Negeri 7 Palembang. Skripsi Universitas PGRI Palembang: Tidak Dipublikasikan.

Baroroh, Ahmad. 2013.Implementasi Pelaksanaan Pendidikan. Bandung: Rineka Cipta.

Burhanuddin, Arief. 2009.Kegiatan Konferensi Kasus. Jakarta; Rineka Cipta.

Hidayat, Muhammad. 2012. Masalah Sosial Remaja. Bandung: Alfabeta.

Hikmawati, Fenti. 2011. Bimbingan dan Konseling. Jakarta: Rajawali Pers.

Kristiani, Ana. 2014. Peran Wali Kelas dalam Membantu Guru Mata Pelajaran. 
Lestari, Mugi. 2013. Kompetensi Profesional Guru Bimbingan dan Konseling Dalam Pelaksanaan Pelayanan Bimbingan dan Konseling. Skripsi Unviersitas Negeri Semarang: Tidak Dipublikasikan.

Mudjiono, Anas. 2012.Belajar dan Pembelajaran. Jakarta: Rineka Cipta.

Moleong, Lexy. 2010. Penelitian: Kualitatif. Bandung: Alfabeta.

Nasruddin. 2012. Penelitian Strategi Guru Dalam Mengatasi Siswa yang Bermasalah. Skripsi Abulyatama Aceh: Tidak Dipublikasikan.

Ngalimun. 2014. Bimbingan Konseling di SD/MI Suatu Pendekatan Proses. Yogyakarta: Aswaja Pressindo.

Nurihsan, Juntika Ahmad. 2014. Pengantar Bimbingan dan Konseling. Jakarta: Rineka Cipta.

Pasaribu, Dora. 2012. Peran Wali Kelas Dalam Pelaksanaan Bimbinan Konseling di SMP Azharyah Palembang. Skripsi Universitas PGRI Palembang: Tidak Dipublikasikan.

Pembayun. 2017. Peran guru kelas Dalam pelaksanaan bimbingan dan konseling Di sd Negeri 2 Sudagaran Kecamatan Banyumas Kabupaten Banyumas. Skripsi Universitas Negeri Semarang: Tidak Dipublikasikan.

Prayitno. 2013. Dasar-dasar Bimbingan dan Konseling. Jakarta: Rineka Cipta.

Setyoningtyas, Restu. 2014. Persepsi Guru BK Tentang Kompetensi Konselor di Sekolah Dasar Swasta Kota Semarang. Skripsi Unviersitas Negeri Semarang: Tidak Dipublikasikan.

Sudjarat. 2011. Psikologi Konseling. Jakarta: Rajawali Pers.

Tohirin. 2015.Bimbingan dan Konseling di Sekolah dan Madrasah. Jakarta: PT Raja Grafindo Persada.

Rasyid. 2014. Analisis Pendekatan Realitas dalam Bimbingan dan Konseling di SMA Negeri 1 Sragen. Skripsi: Univeristas Negeri Semarang, tidak dipublikasikan.

Salahudin. 2016. Bimbingan dan Konseling. Jakarta: Rineka Cipta.

Soejipto \& Kosasih. 2011. Jurnal Peran Wali Kelas dalam Sekolah. Jakarta: Tidak Dipublikasikan.

Sukardi, Ketut Dewa. 2012. Psikologi Perkembangan. Jakarta: Rineka Cipta.

Tirtarharja dan Sulo. 2013. Pengantar Pendidikan. Jakarta : PT Rineka Cipta. 
Undang-Undang Sisdiknas No. 20 Tahun 2003 tentang Pendidikan Nasional.

Universitas PGRI. 2019. Pedoman Penulisan Skripsi. Palembang: Universitas PGRI Palembang.

Walgito. 2014. Psikologi Perkembangan. Jakarta: Rineka Cipta.

Willis, Sofyan. 2012. Perkembangan Remaja. Jakarta: Rineka Cipta.

Winkel dan Hastuti. 2014. Bimbingan Dan Konseling Di Institusi Pendidikan. Yogyakarta: Media Abadi.

Wulandari, Betty. 2013. Hambatan Pelaksanaan Layanan Konseling Kelompok pada SMP Negeri se-Kabupaten Wonogiri Tahun Pelajaran 2012/2013. Skripsi Unviersitas Negeri Semarang: Tidak Dipublikasikan.

Zurriyati, Ery. 2014.. Peranan dan Kerjasama Personil Sekolah dalam Pelayanan Bimbingan dan Konseling di Sekolah. Jurnal: Tidak Dipublikasikan. 